\title{
No evidence for genetic linkage of Gilles de la Tourette syndrome on chromosomes 7 and 18
}

\author{
P Heutink, B J M van de Wetering, G J Breedveld, J Weber, L A Sandkuyl, E J Devor, A Heiberg,
} M F Niermeijer, B A Oostra

\begin{abstract}
Gilles de la Tourette syndrome is a heritable neuropsychiatric disorder. In order to determine the chromosomal localisation of the locus involved, genetic linkage studies were initiated in six extended families. The Gilles de la Tourette gene has been tentatively assigned to chromosome $18 \mathrm{q} 22.1$. In our present study no evidence for genetic linkage on chromosome 18 and chromosome 7 was obtained. Data from the markers tested made it possible to exclude the whole of chromosome 18 and the chromosome 7q21.3-qter region as a site for the Gilles de la Tourette gene.
\end{abstract}

Gilles de la Tourette syndrome (GTS) is a neuropsychiatric disorder with an unknown aetiology. The syndrome is characterised by recurrent, involuntary, repetitive, multiple motor and vocal tics. In many patients associated behavioural problems like

Department of Clinical Genetics, Erasmus University, PO Box 1738, 3000 DR Rotterdam, and University Hospital Rotterdam-Dijkzigt, The Netherlands.

P Heutink, G J Breedveld, L A Sandkuyl, M F Niermeijer

Department of Psychiatry, Erasmus University, University Hospital Rotterdam-Dijkzigt, Rotterdam, The Netherlands.

B J $M$ van de Wetering

Marshfield Medical Foundation, Marshfield, Wisconsin, USA.

J Weber

Department of Psychiatry, Washington University School of Medicine, St Louis, Missouri, USA.

E Devor

Frambu Helsesenter, Siggerud, Oslo, Norway.

A Heiberg

Department of Cell Biology, Erasmus University, Rotterdam, The Netherlands.

B A Oostra

Correspondence to Dr Heutink.

Received for publication 23 November 1989.

Revised version accepted for publication 18 January 1990. obsessive compulsive behaviour and copro- and echophenomena are observed. ${ }^{1}$

There is strong evidence that GTS is genetically determined. The exact mode of inheritance, however, is still a matter of discussion. Both single major locus and multifactorial models have been proposed. ${ }^{1-6}$ The most widely held hypothesis states that a single autosomal dominant gene with reduced penetrance is involved. ${ }^{6}$ However, it has been discussed that associated behavioural symptoms should be considered as variant expressions of the presumed genetic defect responsible for GTS. There is general agreement that the chronic tic syndromes, according to DSMIII-R criteria, ${ }^{7}$ in families afflicted with GTS are variant phenotypes of the GTS gene defect. ${ }^{2}$

Comings et $^{\mathrm{al}} \mathrm{l}^{\mathrm{b}}$ presented evidence for the localisation of the GTS gene. They reported a $46, t(7 ; 18)$ (q22;q22.1) reciprocal translocation in six relatives suffering from GTS. No support for linkage was found between the breakpoint on chromosome 7q22 and the COLA1 locus at 7q21.3-q22.1, suggesting a localisation of the GTS gene near the 18q22.1 breakpoint. Donnai ${ }^{9}$ reported a GTS patient with a deletion of the long arm of chromosome 18 at 18q22.2. These findings led to the tentative assignment of the GTS gene to chromosome 18q22.1. At $18 \mathrm{q} 21$, a candidate gene, gastrin releasing peptide (GRP), has been localised coding for a neuropeptidelike protein. ${ }^{10} 11$

In order to determine the chromosomal location of the GTS gene, we started genetic linkage studies in five families of Dutch origin and in one family of Norwegian origin. In our present study we found no support for linkage on either chromosome 18 or chromosome 7, including the COLA1 locus (7q21.3q22.1) near the translocation breakpoint.

\section{Material and methods \\ FAMILY MATERIAL}

Clinical and genetic studies were performed in five Dutch families and one Norwegian family. Complete pedigree data and methods of ascertainment will be published elsewhere (van de Wetering et al, in preparation) and are briefly summarised here.

All subjects were investigated using a standardised 
psychiatric interview with an added section on GTS and tics (Yale Scale, Dr D L Pauls, New Haven). Only those with GTS or tic syndrome, according to DSMIII-R criteria, ${ }^{7}$ were regarded as affected. The interviews were reviewed by an independent psychiatrist and a neurologist without previous knowledge of the family history. A total of 236 subjects was investigated, of whom 48 were considered to be affected.

Pedigrees of the families used in this study are not shown to protect the privacy of the subjects that collaborated in this study. However, pedigrees can be sent to investigators only, on request.

\section{DNA ANALYSIS}

DNA was isolated from peripheral blood lymphocytes of family members as described by Miller et al. ${ }^{12}$ DNA was digested with various restriction enzymes (Boehringer, Pharmarcia, BRL) according to the manufacturer's instructions. Gel electrophoresis of $8 \mu \mathrm{g}$ DNA samples on $0.7 \%$ agarose gels, and DNA immobilisation by alkaline blotting onto nylon membranes (Gene Screen plus), were performed according to standard procedures. ${ }^{13}$ Hybridisation conditions were as described by Maniatis et $a l^{13}$ and washing was performed at $65^{\circ} \mathrm{C}$ in $0.1 \times S S C$ final stringency. DNA was labelled by random hexamer priming according to Feinberg and Vogelstein. ${ }^{14}$

Markers B74 (D18S3), OLVIIA8 (D18S7), OS-4 (D18S5), pHF12-62 (D18S1), and pERT25 (D18S11) were used as reference points for chromosome 18 , as they had been mapped previously by physical methods, and were used for the construction of a continuous linkage map for chromosome $18 .{ }^{15}$ They were kindly provided by Drs J L Mandel, $\mathrm{H}$ Olek, $\mathrm{H}$ Tateishi, $R$ White, and $U$ Müller, respectively. Markers OLVIIE10 and GRP have previously been described $^{16} 17$ and shown to map to chromosome 18 .

Markers pJ2 (TCRB), Cgamma (TCRG), pMetH (MET), NJ3 (COLAl), pTHH28 (D7S37l), pRMU7.4 (D7S370), pYNB3.1R (D7S372), C33 (D7S126), TM102L (D7S135), and pB79A (D7S13) have previously been mapped on chromosome 7 and used in a linkage map. ${ }^{18}$ In our present study they were used as reference points for chromosome 7 . These markers were kindly provided by Drs $T$ W Mak, R White, P Tsipouras, Y Nakamura, L Tsui, and $\mathrm{J}$ Schmidtke, respectively. Markers $\mathrm{pXV}-2 \mathrm{C}$ (D7S23) and TN127 (D7S144) have been described previously and shown to map to chromosome $7 .{ }^{19} 20$

\section{LINKAGE ANALYSIS}

Linkage analysis was performed using the LINKAGE program package version 5.03. ${ }^{21} 22$ The GTS gene frequency was estimated to be 0.003 , with a male penetrance of 0.999 and a female penetrance of 0.56 .
The correction for possible phenocopies was $0.0002 .^{\circ}$ Two point linkage analysis was performed with the MLINK program and multipoint analysis with the LINKMAP program using Haldane's mapping function for interference. No allowance was made for spontaneous mutations. In the multipoint analysis we assumed a constant sex ratio for crossing over of $2 \cdot 1$ (female/male) for chromosome $18 .{ }^{15}$ For chromosome 7 we assumed a constant sex ratio for crossing over of $2 \cdot 0 .{ }^{18} \mathrm{~A}$ lod score of at least $3 \cdot 0$ was considered as evidence for genetic linkage, and a lod score of $-2 \cdot 0$ was considered as evidence for exclusion of linkage, for the assumed model of a single dominant gene with reduced penetrance. ${ }^{23}$

\section{Results and discussion}

Chromosome 18 markers were tested in six extended families and a linkage map was constructed using the continuous linkage map of $\mathrm{O}^{\prime}$ Connell et $\mathrm{al}^{15}$ as a basis. Mapping the genetic distances of corresponding markers B74, pHF12-62, OLVIIA8, OS-4, and pERT25 with our own material differed only marginally from the O'Connell mapping distances. Additional markers OLVIIE10 and GRP were then mapped, with our family material, onto the fixed O'Connell linkage map.

Comings $e t a l^{8}$ and Donnai ${ }^{9}$ postulated that the gene responsible for GTS resides on chromosome 18q22.1. Markers OLVIIE10 at 18q21.3, GRP at $18 \mathrm{q} 21$, OS -4 at $18 \mathrm{q} 21-\mathrm{qter}$, and pERT 25 at $18 \mathrm{q} 23$

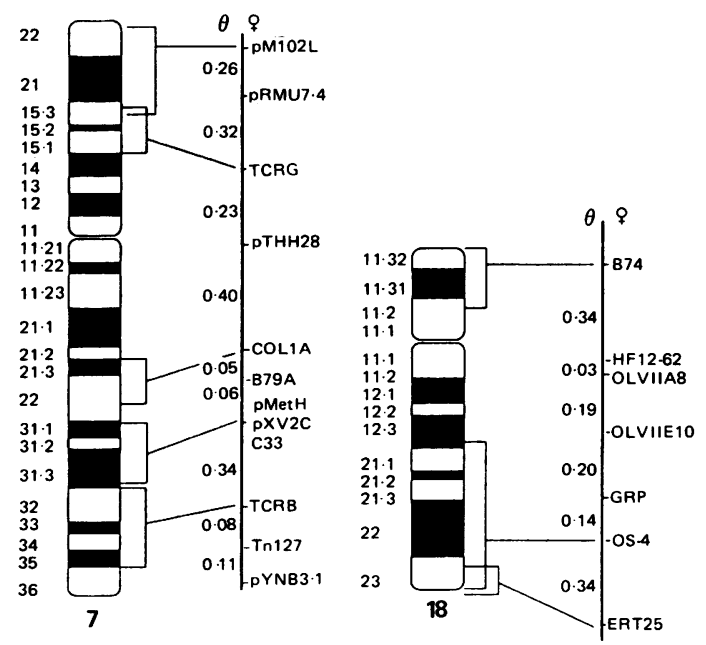

Figure I Female specific genetic maps of chromosomes 7 and 18. Physical locations are indicated where known. Marker order and map distances are based on the linkage maps of O'Connell et $a l^{15} 18$ and mapping studies with our family material. Map distances are presented as $\theta$, assuming a constant female/male crossing over ratio of $2 \cdot 0$ for chromosome 7 and $2 \cdot 1$ for chromosome 18. 
map in the region surrounding the $t(7 ; 18)(q 22 ; q 22.1)$ translocation breakpoint. ${ }^{24}$ Given the linkage map and the cytogenetic maps ${ }^{15} 24$ (fig 1), the most likely localisation for the translocation breakpoint is between markers OLVIIE10 and OS -4 .

Lod scores for the two point analysis of chromosome 18 between GTS and marker loci are shown in table 1. Only subjects presenting GTS or tic syndrome were included as affected in our present study. None of the markers tested showed evidence for linkage and they excluded linkage for the genetic distance mentioned in table 1. Using multipoint analysis (fig 2),
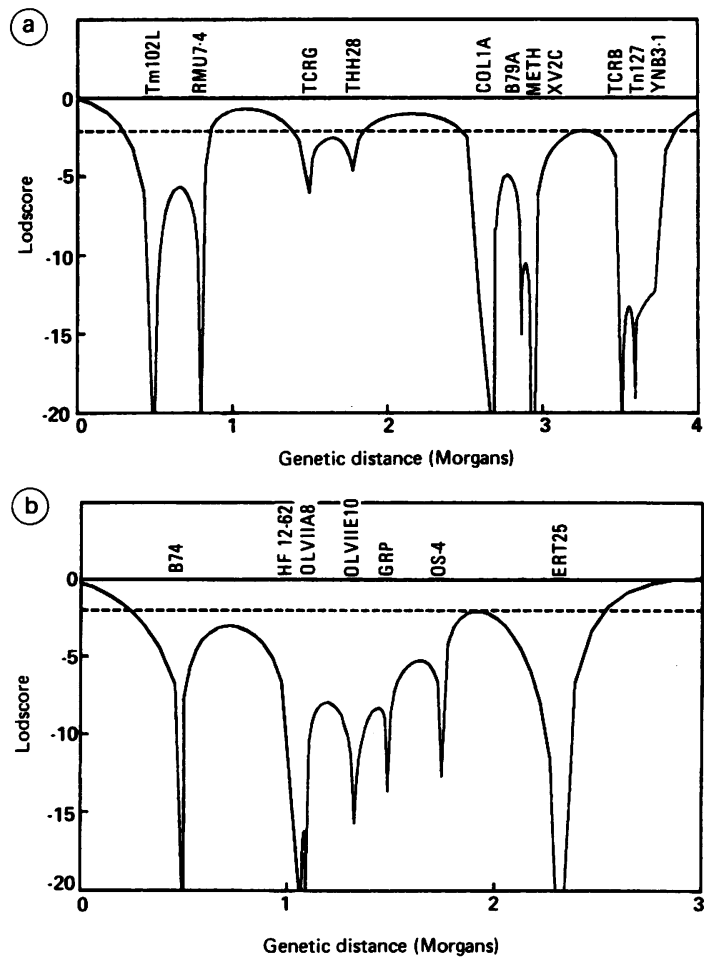

Figure 2 Multipoint linkage analysis showing the exclusion of the GTS locus from chromosome 7q21.3-qter (a) and chromosome $18(b)$. Dotted line represents $a$ value of -2 . we obtained lod scores of at least -5 for the translocation breakpoint region between markers OLVIIE10 and OS -4 . A lod score of at least -2 was obtained for the complete linkage map of chromosome 18. This value is generally accepted as evidence for the exclusion of linkage. ${ }^{23}$ We therefore conclude that chromosome 18 can be excluded as a site for the GTS gene. These results are not in agreement with the findings of Comings et $^{2 l^{8}}$ and Donnai. ${ }^{9}$

Another possible site for the GTS gene would be the breakpoint of the translocation on chromosome $7 \mathrm{q} 22$ reported by Comings et al. ${ }^{8}$ We have tested several RFLP markers on chromosome 7 with our family material, and a linkage map was constructed (table 2). Comparison of our linkage map with the primary linkage map of O'Connell et $a^{18}$ gave marginal differences only, except for marker C33, which we mapped at $\theta=0.01$ telomeric to pMetH instead of $\theta=0.11$ in the O'Connell data. Our results are consistent with the findings of Rommens et al. ${ }^{19}$ To avoid possible mapping errors we did not include marker $\mathrm{C} 33$ in the multipoint analysis. Marker TN127, not on the primary linkage map of O'Connell et $a l,{ }^{18}$ was mapped using our family material and added to the combined linkage map (fig 1).

For none of the markers tested on chromosome 7 did we find evidence for linkage, including the COLA1 locus which is located proximal to the EPO locus at 7q21 and thus must be located proximal to the presumed breakpoint of the translocation. ${ }^{24}$ With multipoint analysis we have been able to exclude part of chromosome $7 p$ and the $7 q 21.3-q$ ter region including the translocation breakpoint region. The region around marker $\mathrm{C} 33$ is excluded by flanking markers pMetH, pXV2C, and TCRB in the two point analysis as well as in the multipoint analysis, even if we assume that marker $\mathrm{C} 33$ is localised at $\theta=0.11$ to pMetH.

With the exclusion of chromosome 18 as a possible site for the GTS gene and the exclusion of the 7q21.3-qter region of chromosome 7, we conclude that the 46,t $(7 ; 18)(q 22 ; q 22.1)$ reciprocal translocation is not linked to the gene responsible for the Gilles de la Tourette syndrome. However, genetic heterogeneity could mask a positive result. In this study, all families

Table 1 Two point linkage data for chromosome 18.

\begin{tabular}{|c|c|c|c|c|c|c|c|c|}
\hline \multirow[b]{2}{*}{ Probe } & \multicolumn{7}{|c|}{ Recombination fraction $(\Theta)$} & \multirow[b]{2}{*}{ Exclusion } \\
\hline & $0 \cdot 0$ & 0.05 & $0 \cdot 1$ & 0.15 & $0 \cdot 2$ & 0.3 & 0.4 & \\
\hline $\begin{array}{l}\text { B74 } \\
\text { pHF12-62 } \\
\text { OLVIIA8 } \\
\text { OLVII10 } \\
\text { GRP } \\
\text { OS4 } \\
\text { pERT25 }\end{array}$ & $\begin{array}{l}-23 \cdot 46 \\
-15 \cdot 89 \\
-14 \cdot 33 \\
-13 \cdot 88 \\
-10 \cdot 26 \\
-12 \cdot 77 \\
-25 \cdot 07\end{array}$ & $\begin{array}{l}-6 \cdot 68 \\
-3 \cdot 92 \\
-3 \cdot 92 \\
-5 \cdot 39 \\
-2 \cdot 76 \\
-4 \cdot 32 \\
-8 \cdot 04\end{array}$ & $\begin{array}{l}-4 \cdot 24 \\
-2 \cdot 18 \\
-2 \cdot 22 \\
-3 \cdot 34 \\
-1 \cdot 84 \\
-2 \cdot 83 \\
-4 \cdot 47\end{array}$ & $\begin{array}{l}-2 \cdot 86 \\
-1 \cdot 26 \\
-1 \cdot 32 \\
-2 \cdot 20 \\
-1 \cdot 30 \\
-1 \cdot 93 \\
-2 \cdot 61\end{array}$ & $\begin{array}{l}-1.96 \\
-0.69 \\
-0.77 \\
-1.46 \\
-0.91 \\
-1.31 \\
-1.50\end{array}$ & $\begin{array}{l}-0.85 \\
-0.11 \\
-0.21 \\
-0.62 \\
-0.40 \\
-0.51 \\
-0.44\end{array}$ & $\begin{array}{r}-0.26 \\
0.07 \\
-0.02 \\
-0.24 \\
-0.11 \\
-0.11 \\
-0.11\end{array}$ & $\begin{array}{r}25 \\
11 \\
11 \\
18 \\
5 \\
17 \\
18\end{array}$ \\
\hline
\end{tabular}

Centimorgans definitely excluded on either site of the tested marker. A lod score of -2 or less was assumed as defirite proof of exclusion. 
Table 2 Two point linkage data for chromosome 7.

\begin{tabular}{|c|c|c|c|c|c|c|c|c|}
\hline \multirow[b]{2}{*}{ Probe } & \multicolumn{7}{|c|}{ Recombination fraction ( $(0)$} & \multirow[b]{2}{*}{ Exclusion } \\
\hline & 0.0 & 0.05 & $0 \cdot 1$ & $0 \cdot 15$ & $0 \cdot 2$ & $0 \cdot 3$ & $0 \cdot 4$ & \\
\hline $\begin{array}{l}\text { Tm102L } \\
\text { TCRG } \\
\text { pRMU7.4 } \\
\text { pTHH28 } \\
\text { COL1A } \\
\text { pB79A } \\
\text { pMetH } \\
\text { pXV2C } \\
\text { C33 } \\
\text { TCRB } \\
\text { TN127 } \\
\text { pYNB3.1 }\end{array}$ & $\begin{array}{r}-22.62 \\
-12.68 \\
-21.01 \\
-11.04 \\
-13.62 \\
-12.28 \\
-17.36 \\
-25 \cdot 28 \\
-1.54 \\
-21 \cdot 18 \\
-15.73 \\
-7.28\end{array}$ & $\begin{array}{r}-5 \cdot 09 \\
-4.90 \\
-5.06 \\
-2.78 \\
-2 \cdot 73 \\
-3.28 \\
-3.91 \\
-6.47 \\
0.04 \\
-6.15 \\
-4.98 \\
-2.63\end{array}$ & $\begin{array}{r}-2.48 \\
-3.29 \\
-2.92 \\
-1.43 \\
-1.26 \\
-1.75 \\
-1.95 \\
-3.46 \\
0.20 \\
-3.63 \\
-3.05 \\
-1.45\end{array}$ & $\begin{array}{r}-1 \cdot 17 \\
-2 \cdot 29 \\
-1.76 \\
-0.75 \\
-0.54 \\
-0.93 \\
-1.00 \\
-1.93 \\
0.23 \\
-2.20 \\
-1.99 \\
-0.82\end{array}$ & $\begin{array}{r}-0.43 \\
-1.60 \\
-1.04 \\
-0.36 \\
-0.13 \\
-0.44 \\
-0.47 \\
-1.02 \\
0.21 \\
-1.28 \\
-1.31 \\
-0.43\end{array}$ & $\begin{array}{r}0.19 \\
-0.73 \\
-0.58 \\
-0.01 \\
0.23 \\
0.02 \\
-0.01 \\
-0.13 \\
0.12 \\
-0.30 \\
-0.52 \\
-0.05\end{array}$ & $\begin{array}{r}0.22 \\
-0.26 \\
-0.30 \\
0.07 \\
0.23 \\
0.10 \\
0.06 \\
0.11 \\
0.03 \\
0.04 \\
-0.14 \\
0.05\end{array}$ & $\begin{array}{r}11 \\
18 \\
11 \\
5 \\
5 \\
5 \\
11 \\
17 \\
0 \\
18 \\
18 \\
5\end{array}$ \\
\hline
\end{tabular}

${ }^{*}$ Centimorgans definitely excluded on either site of the tested marker. A lod score of -2 or less was assumed as definite proof of exclusion.

contributed to the negative lod scores on both chromosomes.

Currently, we are performing collaborative genetic linkage studies on other parts of the genome in order to find the location of the GTS gene. ${ }^{25}$ Chromosomal rearrangements in families suffering from GTS could facilitate the localisation of the GTS gene, but should be followed by extensive linkage studies in order to obtain definite proof for genetic linkage.

This work was supported by the University Hospital Rotterdam-Dijkzigt and the American Tourette Syndrome Association, New York. The authors wish to thank Dr D L Pauls for providing the Yale Scale, and Professor Dr H Galjaard and Mrs S L Levi for their continuous support.

1 Shapiro AK, Shapiro ES, Young JG, Feinberg FE. Gilles de la Tourette syndrome. 2nd ed. New York: Raven Press, 1988.

2 Kidd KK, Pauls DL. Genetic hypotheses for Tourette syndrome. In: Friedhoff AJ, Chase TN, eds. Advances in neurology. Vol 35. New York: Raven Press, 1982:243-9.

3 Baron M, Shapiro ES, Shapiro AK, Rainer JD. Genetic analysis of Tourette syndrome suggesting major gene defect. Am f Hum Genet 1981;36:767-75.

4 Comings DE, Comings BG, Devor EJ, Cloninger CR. Detection of a major gene for Gilles de la Tourette. Am $\mathcal{f}$ Hum Genet 1984;36:586-600.

5 Devor EJ. Complex segregation analysis of Gilles de la Tourette syndrome: further evidence for a major locus mode of transmission. Am f Hum Genet 1984;36:704-9.

6 Pauls DL, Leckman JF. The inheritance of Gilles de la Tourette's syndrome and associated behaviours: evidence for autosomal dominant transmission. N Engl 7 Med 1986;315:993-7.

7 American Psychiatric Association. Diagnostic and statistical manual of mental disorders. 3rd ed, revised. Washington DC: APA, 1987.

8 Comings DE, Comings BG, Dietz G, et al. Linkage studies in Tourette syndrome. Am $\mathcal{F}$ Hum Genet 1986;39:447.

9 Donnai D. Gene location in Tourette syndrome. Lancet 1987; 627.
10 Shaw D, Eiberg H. Report of the committee for chromosomes 17 , 18, and 19. HGM9. Cytogenet Cell Genet 1987;46:242-56.

11 Spindel ER, Chin WW, Price J, Rees LH, Besser GM, Habener JF. Cloning and characterization of $\mathrm{cDNAs}$ encoding human gastrin-releasing peptide. Proc Natl Acad Sci USA 1984;81: 5699-703.

12 Miller SA, Dykes DD, Polesky HF. A simple salting out procedure for extracting DNA from human nucleated cells. Nucleic Acids Res 1988;16:1214.

13 Maniatis T, Fritsch EF, Sambrook J. Molecular cloning: a laboratory manual. New York: Cold Spring Harbor Laboratory, 1982.

14 Feinberg A, Vogelstein B. A technique for radiolabelling DNA restriction endonuclease fragments to high specific activity. Anal Biochem 1983;132:6-13.

15 O'Connell P, Lathrop GM, Leppert M, et al. Twelve loci form a continuous linkage map for human chromosome 18. Genomics 1988;3:367-72.

16 Marlkens F, Delattre O, Bernard A, Olschwang S, Dutrillaux B, Thomas G. RFLP identified by the anonymous DNA segment OLVIIE10 at 18q21.3. Nucleic Acids Res 1987;15:1348.

17 Detera-Wadleigh SD, Anderson S, Spindel ER. A frequent PvuII RFLP of the human gastrin releasing gene. Nucleic Acids Res $1987 ; 15: 375$.

18 O'Connell P, Lathrop GM, Leppert M, et al. A primary genetic linkage map of chromosome 7. Cytogenet Cell Genet 1987;46: 672.

19 Rommens JM, Zengerling S, Burns J, et al. Identification and regional localisation of DNA markers on chromosome 7 for the cloning of the cystic fibrosis gene. Am f Hum Genet 1988;43: 645-63.

20 Estivill X, Farrall M, Scambler PJ, et al. A candidate for the cystic fibrosis locus isolated by selection for methylation free islands. Nature 1987;326:840-5.

21 Lathrop GM, Lalouel JM. Easy calculations of lodscores and genetic risks on a small computer. Am $\mathcal{F}$ Hum Genet 1984;36: $460-5$.

22 Lathrop GM, Lalouel JM, Julier C, Ott J. Strategies for multilocus linkage analysis in humans. Proc Natl Acad Sci USA 1984;81:3443-6.

23 Conneally PM, Rivas ML. Linkage analysis in man. In: Harris $\mathbf{H}$, Hirschhorn K, eds. Advances in human genetics. Vol 10. New York, London: Plenum Press, 1980:209-61.

24 Tsui LC, Farrall M, Donis-Keller H. Report of the committee on the genetic constitution of chromosome 7 and 8. HGM9. Cytogenet Cell Genet 1989;51:166-201.

25 Devor EJ, Grandy DK, Civelli O, et al. Genetic linkage is excluded for the $D_{2}$-dopamine receptor lambdaHD2G1 and flanking loci on chromosome 11q22-q23 in Tourette syndrome. Hum Hered 1990;40:105-8. 